

\title{
Reduction of sulfur and oxidized forms of nitrogen by bacteria of Desulfuromonas sp., isolated from Yavorivske Lake, under the influence of ferrum citrate
}

\author{
O. M. Moroz, S. O. Hnatush, O. D. Maslovska, G. V. Yavorska, B. M. Borsukevych \\ Ivan Franko National University of Lviv, Lviv, Ukraine
}

Article info

Received 05.01.2020

Received in revised form 01.02 .2020

Accepted 02.02.2020

Ivan Franko National

University of Lviv,

Hrushevsky st., 4,

Lviv, 79005, Ukraine

Tel.: +38-067-811-86-44.

E-mail:

oksana.moroz@lnu.edu.ua

Moroz, O. M., Hnatush, S. O., Maslovska, O. D., Yavorska, G. V., \& Borsukevych, B. M. (2020). Reduction of sulfur and oxidized forms of nitrogen by bacteria of Desulfuromonas sp., isolated from Yavorivse Lake, under the influence of ferrum citrate. Biosystems Diversity, 28(1), 53-59. doi:10.15421/012009

Technogenic reservoirs mainly contain several possible electron acceptors of anaerobic respiration, many of which are dangerous to the environment. The succession of their reduction (and thus detoxification) by sulfur reducing bacteria is not yet sufficiently studied. We investigated the influence of ferrum (III) citrate, present in the cultivation medium, on the reduction of sulfur, nitrate and nitrite ions by sulfur reducing bacteria Desulfuromonas acetoxidans IMV B-7384, Desulfuromonas sp. Yavor-5 and Desulfuromonas sp. Yavor-7, isolated from Yavorivske Lake. It was established that ferrum (III) citrate inhibits the biomass accumulation and hydrogen sulfide production by bacteria of Desulfuromonas sp. after simultaneous addition to the medium of $3.47 \mathrm{mM} \mathrm{S}^{0}$ and 1.74 $10.41 \mathrm{mM}$ ferrum (III) citrate, as compared with growth and hydrogen sulfide production by bacteria in the medium with only sulfur. In the medium with the same initial content $(3.47 \mathrm{mM}) \mathrm{S}^{0}$ and ferrum (III) citrate bacteria produced ferrum (II) ions at concentrations 3.5-3.9 times higher than that of hydrogen sulfide. Ferrum (III) citrate inhibits the biomass accumulation, the nitrate or nitrite ions reduction and the ammonium ions production by bacteria of Desulfuromonas sp. after simultaneous addition to the medium of $3.47 \mathrm{mM} \mathrm{NaNO}_{3}$ or $\mathrm{NaNO}_{2}$ and 1.74-10.41 mM ferrum (III) citrate. In the medium with the same initial content $\left(3.47 \mathrm{mM}^{\mathrm{m}} \mathrm{NaNO}_{3}\right.$ and ferrum (III) citrate, bacteria produced ammonium ions at concentrations in 1.1 times higher than that of ferrum (II) ions. In the medium with the same initial content $(3.47 \mathrm{mM}) \mathrm{NaNO}_{2}$ and ferrum (III) citrate, bacteria reduced 1.5-1.6 times more ferrum (III) than nitrite ions with production of ferrum (II) ions at concentrations 1.7 times higher than that of ammonium ions. The process of nitrate reduction carried out by bacteria of Desulfuromonas genus was less sensitive to the negative influence of ferrum (III) citrate, compared to the process of nitrite ions reduction. When the reduction of nitrate ions by bacteria in the presence of $1.74-10.41 \mathrm{mM}$ ferrum (III) citrate decreased by 1.4-2.2 times, then the reduction of nitrite ions decreased by 1.8-3.2 times compared to their reduction in media with only $\mathrm{NaNO}_{3}$ or $\mathrm{NaNO}_{2}$, respectively. Although the reduction of ferrum (III) by cells in media with $3.47 \mathrm{mM} \mathrm{S}$, $\mathrm{NaNO}_{3}$ or $\mathrm{NaNO}_{2}$ and 1.74-10.41 mM ferrum (III) citrate decreased by 1.6-2.7, 1.6-2.7 and 1.1-2.2 times, respectively, compared to the reduction in medium with only ferrum (III) citrate, the investigated strains of bacteria were resistant to high concentrations of trivalent ferrum compounds and can therefore can be used in technologies of complex purification of environments polluted by heavy metal and nitrogen compounds.

Keywords: sulfur reducing bacteria; electron acceptors; ferrum; sulfur; nitrates; nitrites.

\section{Introduction}

Sulfidogenic bacteria of the Desulfuromonas genus in the process of anaerobic respiration can use sulfur, oxidized forms of nitrogen or heavy metals, in particular, ferrum (III) as electron acceptors. Anthropogenically altered environments are most often contaminated with many organic and inorganic toxic compounds. Microorganisms are involved in their oxidative and reductive transformation.

The Yavoriv state mining and chemical enterprise "Sulfur" with an area of $74 \mathrm{~km}^{2}$ ceased industrial activity in 1993. The open-pit mining of sulfur ore in the 1970s led to the formation of one of the largest quarries in the world, covering an area of 1,080 hectares. Since 1998, a large area of the deposit, including the central well and the adjacent branches of quarry, has been flooded with water. As a result, Yavorivske Lake with an area of more than 700 hectares and a depth of more than $90 \mathrm{~m}$ was formed (Baran et al., 2003; Gudz et al., 2004; Gaidin \& Zozulia, 2009). Because of the open-pit mining of sulfur, components of the natural evolutionarily formed biogeocenosis were destroyed. The technogenic landscape was formed, the recultivation of which led to the formation of a qualitatively new biogeocenosis, in particular, microbocenosis. Its components are constantly interacting with each other and with the rock brought to the surface from previously unavailable depths. New hydrogeological and hydrological conditions are formed, and a new grouping of microorganisms is created that does not have analo- gues in nature. A distinctive feature of the sulfur quarry is the presence of aquifers in the sulfate-carbonate layers of the Neogene, which contain large amounts of hydrogen sulfide (Gaidin \& Zozulia, 2009). Therefore, the metabolic processes carried out by sulfidogenic bacteria determine the functioning of the microbocenosis of the lake area and are an essential factor in evaluation of the ecological status of the transformed biotope (Moroz et al., 2008; Tarabas et al., 2017).

Heavy metals, hydrogen sulfide, nitrates, nitrites and other oxidized nitrogen compounds are the most dangerous pollutants of the environment. A considerable share of them is not included in the natural cycle, accumulates in the biosphere and causes a negative influence on the structure of environment and man. In the water of Yavorivske Lake at all depths the concentrations of compounds of sulfur $\left(\mathrm{SO}_{4}^{2-}\right.$ up to 1529 $1725 \mathrm{mg} / \mathrm{L}, \mathrm{H}_{2} \mathrm{~S}$ up to $34.0-47.2 \mathrm{mg} / \mathrm{L}$ ), nitrogen ( $\mathrm{NO}^{3-}$ up to $2.5 \mathrm{mg} / \mathrm{L}$ ) (Moroz et al., 2008; Tarabas et al., 2017) and heavy metals (Mn(II) up to $0.243 \mathrm{mg} / \mathrm{L}, \mathrm{Cd}(\mathrm{II})$ up to $0.031 \mathrm{mg} / \mathrm{L}, \mathrm{Fe}$ (II) up to $0.144 \mathrm{mg} / \mathrm{L}$, $\mathrm{Fe}(\mathrm{III})$ up to $0.342 \mathrm{mg} / \mathrm{L}$, etc.) toxic to living organisms often exceed the maximum admissible norms. Chemical methods of purification of technogenically altered environments are ineffective and energy consuming. The development of new microbial biotechnologies directed at decreasing the content of inorganic toxicants in technogenic ecosystems is an especially relevant task. Strains of microorganisms, in particular, representatives of the sulfidogenic microbiota, isolated from contaminated environments, are adapted to stress factors, so they are most suita2020, 28(1) 
ble for use in the technologies of purification of different substrates (Kuznetsov et al., 2015; Teng et al., 2019).

Sulfur reducing bacteria of the Desulfuromonas genus are obligate anaerobes, they use elemental or polysulfide sulfur, nitrates, nitrites, Lmalate, fumarate, tri- or tetrachlorethylene, oxidized forms of heavy metals as electron acceptors (Hedderich et al., 1999; Sung et al., 2003; Kuever et al., 2005; An \& Picarda, 2015), oxidizing at the same time a number of simple organic compounds to $\mathrm{CO}_{2}$ (Maslovska \& Hnatush, 2013; Vasyliv et al., 2015). Sulfidogenic bacteria attract the attention of researchers as potential agents for the purification of waters contaminated with hydrogen sulfide and heavy metals. Bacteria of the Desulfuromonas genus as a result of dissimilatory sulfur reduction produce the hydrogen sulfide that interacts with divalent metal ions with formation of insoluble sulfides, which are thus removed from the natural cycle. These bacteria oxidize organic substrates using metals with variable valence as electron acceptors (Moroz et al., 2014, 2016), reduce and transform them into forms non-toxic or less toxic for living organisms (Vasyliv et al., 2011; Bilyy et al., 2014; Maslovska et al., 2015). Bacteria of the Desulfuromonas genus contain a large number of various types of cytochromes (Rosenberg et al., 2014). In Desulfuromonas acetoxidans, tri-heme c-type cytochrome c7 is involved not only in sulfur reduction but also functions as Fe(III) reductase (Roden \& Lovley, 1993). Bacteria reduce nitrates and nitrites with the participation of $\mathrm{NADH}_{2}, \mathrm{NAD}(\mathrm{P}) \mathrm{H}$ or reduced quinone to ammonium (carry out their ammonification) (Lengeler et al., 2005, Kozlova et al., 2008). NarGHI nitrate reductase is an enzyme complex consisting of multi-heme b-type cytochrome, proteins with Fe-S clusters and Mo-containing cofactor (Morozkina \& Zvyagilskaya, 2007; Kozlova et al., 2008). Nitrate reduction with the formation of nitrites and their subsequent reduction by a complex of periplasmic dissimilatory nitrite reductases to $\mathrm{NH}^{4+}$ in Wolinella succinogenes and Desulfuromonas sp. is described (Bokranz et al., 1983; Chayka \& Peretyatko, 2018). Most representatives of sulfidogenic bacteria have a nonspecific metal reductase enzyme system that allows them to use compounds of $\mathrm{Fe}(\mathrm{III}), \mathrm{Mn}(\mathrm{IV}), \mathrm{U}(\mathrm{VI}), \mathrm{Cr}(\mathrm{VI}), \mathrm{Cu}(\mathrm{II})$ and other metals as electron acceptors of anaerobic respiration (Kozlova et al., 2008). Soluble and insoluble metal compounds are reduced outside the cells by a system of membrane-bound metal reductases (multi-heme c-type cytochromes) (Gescher \& Kappler, 2012; Richter et al., 2012; Breuer et al., 2015), therefore electrons are released into the medium, allowing these exoelectrogenic anaerobic bacteria to be used in the microbial fuel cells (MFC) as the high effective anode biocatalysts (Fitzgerald et al., 2013; Prokhorova et al., 2017; Simonte et al., 2017). Electric current generation by Desulfuromonas acetoxidans IMV B-7384 in a MFC was described (Bilyy et al., 2014; Vasyliv et al., 2015), and the interrelation between $\mathrm{Fe}$ (III) reduction and exoelectrogenesis performed by this bacteria in the MFC was established (Vasyliv et al., 2016). Metal ions or oxoanions can be reduced by microorganisms not only on the cell surface but also in the internal compartments, in the periplasm and cytoplasm (Richter et al., 2012). In cells, they interact with intracellular reductants (such as amino acids, nucleotides, sugars, organic acids, glutathione, flavoenzymes, vitamins), generate chemical active intermediates, free radicals and can cause oxidative stress (Viti et al., 2012; Maslovska \& Hnatush, 2015; Hnatush \& Maslovska, 2018).

In technogenic reservoirs there are often several possible electron acceptors of anaerobic respiration. The succession of their reduction by microorganisms is not well understood, it may be different in bacteria strains of the same genus (Rosenberg et al., 2014). In various microorganisms, the succession of reduction of elements with variable valence is not always determined by their oxidation-reduction potential, but determined genetically and controlled by complex regulatory mechanisms (Lengeler et al., 2005; Rosenberg et al., 2014). Previously, we have shown that bacteria of the Desulfuromonas genus, isolated from Yavorivske La$\mathrm{ke}$, in addition to sulfur or oxidized forms of nitrogen, can use oxidized forms of heavy metals, in particular, ferrum (III) as terminal electron acceptors (Moroz et al., 2014, 2016). The purpose of this work was to investigate the regularities of sulfur, nitrate or nitrite ions usage by strains of Desulfuromonas sp. bacteria at conditions of simultaneous presence in the medium of another electron acceptor - ferrum (III), to establish the succession of electron acceptors reduction and to determine the efficiency of their possible application in technologies for complex purification of the environment from inorganic toxicants.

\section{Materials and methods}

Sulfur reducing bacteria Desulfuromonas acetoxidans IMV B-7384, Desulfuromonas sp. Yavor-5 and Desulfuromonas sp. Yavor-7, isolated by us earlier from the Yavorivske Lake, were identified at the Microbiology Department of Ivan Franko National University of Lviv (Gudz et al., 2013; Moroz et al., 2013).

Bacteria were grown in Kravtsov-Sorokin medium (Gudz et al., 2014) without $\mathrm{SO}_{4}^{2-}$ and without Mohr's salt of such composition $(\mathrm{g} / \mathrm{L})$ : $\mathrm{NaH}_{2} \mathrm{PO}_{4} \times 12 \mathrm{H}_{2} \mathrm{O}(0.84), \mathrm{K}_{2} \mathrm{HPO}_{4}(0.5), \mathrm{NH}_{4} \mathrm{Cl}(0.16), \mathrm{MgCl}_{2} \times 6 \mathrm{H}_{2} \mathrm{O}$ (0.10), sodium lactate $\left(\mathrm{NaC}_{3} \mathrm{H}_{5} \mathrm{O}_{3}\right)(2.0)$ or sodium citrate $\left(\mathrm{Na}_{3} \mathrm{C}_{6} \mathrm{H}_{5} \mathrm{O}_{7}\right)$ (4.6). Before bacteria seeding $0.05 \mathrm{~mL}$ of $\mathrm{Na}_{2} \mathrm{~S} \times 9 \mathrm{H}_{2} \mathrm{O}(1 \%)$ sterile solution was added to the medium. A sterile $10 \mathrm{~N} \mathrm{NaOH}$ solution was used to provide $\mathrm{pH}$ of the medium to 7.2. Bacteria were sown in medium to initial cells concentration of $0.1 \mathrm{mg} / \mathrm{mL}$. The sulfur was sterilized separately $(0.5 \mathrm{~atm})$ and placed in medium as weighted quantities at concentration of $3.47 \mathrm{mM}$ (concentration of $\mathrm{SO}_{4}^{2-}$ in medium of standard composition). $1 \mathrm{M}$ solutions of $\mathrm{C}_{4} \mathrm{H}_{3} \mathrm{NaO}_{4}, \mathrm{NaNO}_{3}, \mathrm{NaNO}_{2}$ and $\mathrm{FeC}_{6} \mathrm{H}_{5} \mathrm{O}_{7}$ were sterilized separately and placed into the medium before seeding of the cells. Into media with $\mathrm{C}_{4} \mathrm{H}_{3} \mathrm{NaO}_{4}, \mathrm{FeC}_{6} \mathrm{H}_{5} \mathrm{O}_{7}$ or $\mathrm{NaNO}_{3}$ or $\mathrm{NaNO}_{2} 0.017 \mathrm{mM}$ cysteine $\left(\mathrm{C}_{3} \mathrm{H}_{7} \mathrm{NO}_{2} \mathrm{~S}\right)$ was introduced to provide the assimilation needs of bacteria in sulfur (Lengeler et al., 2005). To media with $\mathrm{NaNO}_{3}, \mathrm{NaNO}_{2}$ and $\mathrm{FeC}_{6} \mathrm{H}_{5} \mathrm{O}_{7}$ or without it the $\mathrm{NH}_{4} \mathrm{Cl}$ was not added. Bacteria were grown for 10 days in test tubes $(25 \mathrm{~mL})$, completely topped up by the medium, at a temperature of $30^{\circ} \mathrm{C}$.

To determine the efficiency of sulfur, nitrate, nitrite ions or Fe(III) reduction at simultaneous presence in the medium of two electron acceptors $\left(\mathrm{S}^{0}, \mathrm{NO}^{3-}\right.$ or $\mathrm{NO}^{2-}$ and $\left.\mathrm{Fe}(\mathrm{III})\right)$, cells were previously cultivated in the medium with sodium fumarate $(3.47 \mathrm{mM})$ as an electron acceptor and sodium lactate $(17.86 \mathrm{mM})$ as an electron donor to the middle of the exponential growth phase. They were sown in the medium with sodium citrate $(17.86 \mathrm{mM})$, to which weighted quantities of insoluble in water sterile $\mathrm{S}^{0}$ and sterile solutions of $\mathrm{NaNO}_{3}$ or $\mathrm{NaNO}_{2}$ were added to their final concentration in the medium of $3.47 \mathrm{mM}$ and different volumes of the sterile $\mathrm{FeC}_{6} \mathrm{H}_{5} \mathrm{O}_{7}$ solution to its final concentrations of 1.74 , $3.47,5.21,6.94$ and $10.41 \mathrm{mM}$, which differs by $0.5,1.0,1.5,2.0$ and 3.0 times from the standard electron acceptor content in Kravtsov-Sorokin medium. The cells were also sown in a medium with sodium citrate, to which were added weighted quantities of $\mathrm{S}^{0}$, solutions of $\mathrm{NaNO}_{3}$, $\mathrm{NaNO}_{2}$ or $\mathrm{FeC}_{6} \mathrm{H}_{5} \mathrm{O}_{7}$ to their final concentration in the medium of $3.47 \mathrm{mM}$, to test the bacteria growth in media with sulfur, nitrate, nitrite ions or $\mathrm{Fe}$ (III) as the sole electron acceptor (control). Into the medium without cells the weighted quantities of $\mathrm{S}^{0}$, solutions of $\mathrm{NaNO}_{3}, \mathrm{NaNO}_{2}$ or $\mathrm{FeC}_{6} \mathrm{H}_{5} \mathrm{O}_{7}$ were added at concentration of $3.47 \mathrm{mM}$ to verify their spontaneous reduction. Biomass, the concentrations of nitrate or nitrite, ferrum (II) ions, Fe(III), hydrogen sulfide or ammonium ions in cultural liquid were determined on 10 day of growth. To determine the concentrations of ferrum (II) ions and hydrogen sulfide, the precipitate of $\mathrm{FeS}$, which formed during bacteria cultivation in medium with $\mathrm{S}^{0}$ and $\mathrm{FeC}_{6} \mathrm{H}_{5} \mathrm{O}_{7}$, was dissolved after interaction with $\mathrm{HCl}$ according to the equation: $\mathrm{FeS}+$ $2 \mathrm{HCl} \rightleftarrows \mathrm{FeCl}_{2}+\mathrm{H}_{2} \mathrm{~S}$ (the $\mathrm{HCl}$ concentration exceeded twice the concentration of $\mathrm{S}^{0}$ in the medium and was $6.94 \mathrm{mM}$ ). By the difference between the initial and residual content of electron acceptors in the medium the efficiency (\%) of their reduction by bacteria was calculated, based on the ratio of molar concentrations of reduced by bacteria nitrate, nitrite ions or $\mathrm{Fe}$ (III) in the process of anaerobic respiration and their concentrations at the beginning of cultivation, which were taken as $100 \%$.

Biomass was determined by the turbidimetric method by the optical density of the cell suspension by measuring it at a wavelength of $340 \mathrm{~nm}$ in a cuvette with an optical way of $3 \mathrm{~mm}$ and calculated using the formula: $\mathrm{C}, \mathrm{g} / \mathrm{L}=\left(\mathrm{E}_{340} \times \mathrm{n}\right) / \mathrm{K}$, where $\mathrm{E}_{340}-$ extinction $(\lambda=340 \mathrm{~nm}) ; \mathrm{n}$ - dilution factor; $\mathrm{K}$ - coefficient of recalculation, obtained from the calibration curve of the dependence of extinction from the mass of dry cells, determined by the weight method, and equal to 0.72 (Gudz et al., 2014). In a cultural liquid, separated from the cells by centrifugation ( $4025 \mathrm{~g}, 15 \mathrm{~min}$ ), we determined the concentrations of nitrate ions (after their reduction to ni- 
trites in the presence of $\mathrm{Zn:} \mathrm{MnSO}_{4}$ (1:100) powder as a reducing agent) and nitrite ions by spectrophotometric method which relies on a diazotization reaction with a Griess reagent (n-(1-naphthyl) ethylenediamine dihydrochloride, sulfanil and acetic acid) (Granger, 1996), ferrum (III) (after its reduction to ferrum (II) ions in the acidic medium by interaction with hydroxylamine) and ferrum (II) ions by spectrophotometric method by reaction with o-phenanthroline, hydrogen sulfide by spectrophotometric method for the formation of methylene blue and ammonium ions by colorimetric method for the formation of indophenol (Gudz et al., 2014).

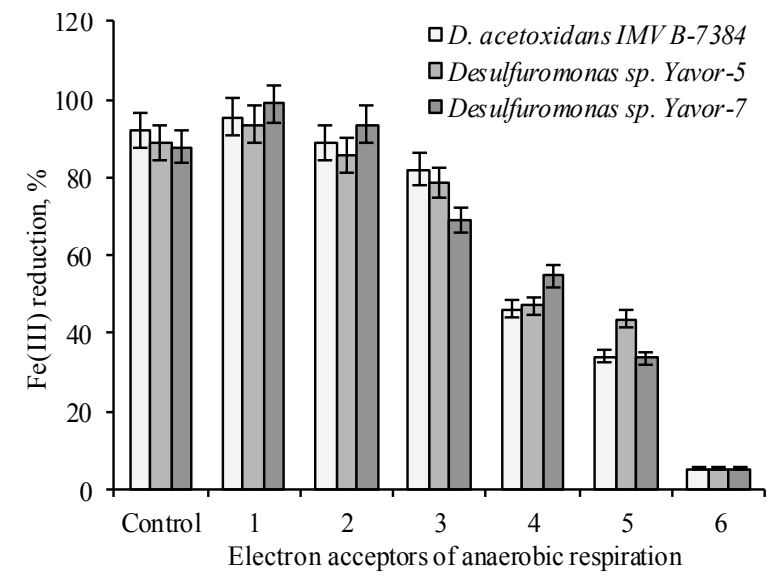

Fig. 1. Efficiency of Fe(III) reduction by Desulfuromonas sp. after 10 days of growth in media with $\mathrm{S}^{0}$ or $\mathrm{FeC}_{6} \mathrm{H}_{5} \mathrm{O}_{7}(\mathrm{M} \pm \mathrm{m}, \mathrm{n}=3)$ : designation on the horizontal axis: control $-3.47 \mathrm{mM} \mathrm{Fe}(\mathrm{IIII})$; $1-3.47 \mathrm{mM} \mathrm{S}^{0}$ and $1.74 \mathrm{mM} \mathrm{Fe}(\mathrm{III}) ; 2-3.47 \mathrm{mM} \mathrm{S}^{0}$ and $3.47 \mathrm{mM}$ $\mathrm{Fe}(\mathrm{III}) ; 3-3.47 \mathrm{mM} \mathrm{S}^{0}$ and $5.21 \mathrm{mM} \mathrm{Fe}(\mathrm{III}) ; 4-3.47 \mathrm{mM} \mathrm{S}^{0}$ and $6.94 \mathrm{mM} \mathrm{Fe}(\mathrm{III}) ; 5-3.47 \mathrm{mM} \mathrm{S}^{0}$ and $10.41 \mathrm{mM} \mathrm{Fe}(\mathrm{III})$; 6-3.47 mM Fe(III) (without bacteria); * $-\mathrm{P}<0.05$

Experiments were repeated three times with three parallel formulations for each variant of experimental and control conditions. The reliability of the difference was evaluated using ANOVA. Differences between the samples were considered reliable at $\mathrm{P}<0.05$.

\section{Results}

To study the influence of ferrum (III) citrate on the sulfur reduction by sulfur reducing bacteria, they were grown in the medium with sodium citrate, to which $3.47 \mathrm{mM} \mathrm{S}^{0}$ and $\mathrm{FeC}_{6} \mathrm{H}_{5} \mathrm{O}_{7}$ at different concentrations were added. The bacteria were also sown in media with sodium citrate and $3.47 \mathrm{mM} \mathrm{S}^{0}$ or $3.47 \mathrm{mM} \mathrm{FeC}_{6} \mathrm{H}_{5} \mathrm{O}_{7}$ to test the use by bacteria of sulfur or ferrum (III) as the sole electron acceptor (Table 1). After 10 days of growth the biomass of bacteria in the medium with $\mathrm{S}^{0}$ was not significantly lower than in the medium with $\mathrm{FeC}_{6} \mathrm{H}_{5} \mathrm{O}_{7}$. After the simultaneous addition of $\mathrm{S}^{0}$ and $\mathrm{Fe}$ (III) to the cultivation medium with growing of ferrum (III) citrate concentrations, a gradual decreasing in the biomass accumulation by bacteria was observed, compared to growth in media with only $\mathrm{S}^{0}$ or $\mathrm{FeC}_{6} \mathrm{H}_{5} \mathrm{O}_{7}$. In the medium with $\mathrm{S}^{0}$ and $10.41 \mathrm{mM} \mathrm{FeC}_{6} \mathrm{H}_{5} \mathrm{O}_{7}$ the growth of bacteria decreased 1.8-2.0 times, compared with growth in the medium with only $\mathrm{S}^{0}$ or $\mathrm{FeC}_{6} \mathrm{H}_{5} \mathrm{O}_{7}$. In the media with $\mathrm{S}^{0}$ and $\mathrm{FeC}_{6} \mathrm{H}_{5} \mathrm{O}_{7}$ with increasing of ferrum (III) citrate concentrations, a gradual decrease was observed in concentrations of hydrogen sulfide produced by bacteria, as compared with its production in the medium with only $\mathrm{S}^{0}$. In media with $\mathrm{S}^{0}$ and $\mathrm{FeC}_{6} \mathrm{H}_{5} \mathrm{O}_{7}$, the cells produced $0.45-0.94 \mathrm{mM}$ hydrogen sulfide (control: $1.60-1.84 \mathrm{mM}$ ). The efficiency of $\mathrm{Fe}$ (III) reduction by bacteria in the medium with $\mathrm{S}^{0}$ and $1.74-5.21 \mathrm{mM} \mathrm{FeC}_{6} \mathrm{H}_{5} \mathrm{O}_{7}$ practically did not differ from their reduction in the medium with ferrum (III) citrate as the sole electron acceptor (87.9-91.9\%), but was found to be 1.6-2.7 times lower at $\mathrm{FeC}_{6} \mathrm{H}_{5} \mathrm{O}_{7}$ concentrations in the medium of 6.94-10.41 mM (Fig. 1). In media with sulfur and ferrum (III) citrate, bacteria produced $1.51-4.40 \mathrm{mM}$ of ferrum (II) ions (control: $2.87-2.94 \mathrm{mM}$ ) (Table 1). In the medium with $\mathrm{S}^{0}$ or $\mathrm{FeC}_{6} \mathrm{H}_{5} \mathrm{O}_{7}$ without bacteria, the efficiency of spontaneous sulfur and $\mathrm{Fe}(\mathrm{III})$ reduction was found to be insignificant and did not exceed 1.2 (calculated according to the produced $\mathrm{H}_{2} \mathrm{~S}$ ) and 5.2\% respectively (Table 1, Fig. 2). Thus, it has been established that ferrum (III) citrate inhibits the biomass accumulation and hydrogen sulfide production by bacteria of Desulfuromonas sp. after simultaneous addition into the medium of $3.47 \mathrm{mM} \mathrm{S}^{0}$ and $1.74-10.41 \mathrm{mM} \mathrm{FeC}_{6} \mathrm{H}_{5} \mathrm{O}_{7}$. In the medium with the same initial content $(3.47 \mathrm{mM}) \mathrm{S}^{0}$ and $\mathrm{FeC}_{6} \mathrm{H}_{5} \mathrm{O}_{7}$, bacteria produced ferrum (II) ions at concentrations 3.5-3.9 times higher than that of hydrogen sulfide.

Table 1

Reduction of $\mathrm{S}^{0}$ and Fe(III) by Desulfuromonas sp. after 10 days of growth in media with $\mathrm{S}^{0}$ and $/ \mathrm{or} \mathrm{FeC}_{6} \mathrm{H}_{5} \mathrm{O}_{7}(\mathrm{M} \pm \mathrm{m}, \mathrm{n}=3)$

\begin{tabular}{|c|c|c|c|c|c|}
\hline Strain & $\begin{array}{c}\text { Electron acceptors } \\
\text { of anaerobic respiration }\end{array}$ & $\begin{array}{c}\text { Residual content } \\
\text { of Fe(III) in cultural liquid, } \mathrm{mM}\end{array}$ & $\begin{array}{l}\mathrm{Fe}^{2+}, \\
\mathrm{mM}\end{array}$ & $\begin{array}{l}\mathrm{S}^{2-} \\
\mathrm{mM}\end{array}$ & $\begin{array}{l}\text { Biomass, } \\
\mathrm{g} / \mathrm{L}\end{array}$ \\
\hline \multirow{9}{*}{$\begin{array}{l}\text { D. acetoxidans } \\
\text { IMV B-7384 }\end{array}$} & $3.47 \mathrm{mM} \mathrm{S}^{0}$ & 0 & 0 & $1.60 \pm 0.03$ & $2.37 \pm 0.02$ \\
\hline & $3.47 \mathrm{mM} \mathrm{S}^{0}(\mathrm{wb})$ & 0 & 0 & $0.04 \pm 0.01$ & $\begin{array}{l}0.01+02 \\
0\end{array}$ \\
\hline & $3.47 \mathrm{mM} \mathrm{S}^{0}$ and $1.74 \mathrm{mM} \mathrm{Fe}$ (III) & $0.08 \pm 0.01$ & $1.51 \pm 0.02$ & $0.87 \pm 0.05$ & $2.55 \pm 0.01$ \\
\hline & $3.47 \mathrm{mM} \mathrm{S}^{0}$ and $3.47 \mathrm{mM} \mathrm{Fe}$ (III) & $0.38 \pm 0.09$ & $2.90 \pm 0.02$ & $0.75 \pm 0.06$ & $2.36 \pm 0.09$ \\
\hline & $3.47 \mathrm{mM} \mathrm{S}^{0}$ and $5.21 \mathrm{mM} \mathrm{Fe}$ (III) & $0.93 \pm 0.07$ & $3.98 \pm 0.04$ & $0.77 \pm 0.01$ & $2.11 \pm 0.04$ \\
\hline & $3.47 \mathrm{mM} \mathrm{S}^{0}$ and $6.94 \mathrm{mM} \mathrm{Fe}$ (III) & $3.74 \pm 0.03$ & $3.15 \pm 0.03$ & $0.53 \pm 0.05$ & $1.43 \pm 0.07$ \\
\hline & $3.47 \mathrm{mM} \mathrm{S}^{0}$ and $10.41 \mathrm{mM} \mathrm{Fe}$ (III) & $6.86 \pm 0.03$ & $3.43 \pm 0.01$ & $0.51 \pm 0.01$ & $1.24 \pm 0.02$ \\
\hline & $3.47 \mathrm{mM} \mathrm{Fe}(\mathrm{IIII})$ & $0.28 \pm 0.01$ & $2.94 \pm 0.04$ & 0 & $2.50 \pm 0.02$ \\
\hline & $3.47 \mathrm{mM} F e($ III) (wb) & $3.29 \pm 0.01$ & $0.17 \pm 0.04$ & 0 & 0 \\
\hline \multirow{9}{*}{$\begin{array}{l}\text { Desulfuromonas sp. } \\
\text { Yavor-5 }\end{array}$} & $3.47 \mathrm{mM} \mathrm{S}^{0}$ & 0 & 0 & $1.68 \pm 0.08$ & $2.20 \pm 0.09$ \\
\hline & $3.47 \mathrm{mM} \mathrm{S}^{0}(\mathrm{wb})$ & 0 & 0 & $0.04 \pm 0.01$ & 0 \\
\hline & $3.47 \mathrm{mM} \mathrm{S}^{0}$ and $1.74 \mathrm{mM} \mathrm{Fe}$ (III) & $0.11 \pm 0.01$ & $1.57 \pm 0.03$ & $0.94 \pm 0.02$ & $2.31 \pm 0.02$ \\
\hline & $3.47 \mathrm{mM} \mathrm{S}^{0}$ and $3.47 \mathrm{mM} \mathrm{Fe}$ (III) & $0.50 \pm 0.03$ & $2.89 \pm 0.04$ & $0.83 \pm 0.07$ & $2.23 \pm 0.08$ \\
\hline & $3.47 \mathrm{mM} \mathrm{S}^{0}$ and $5.21 \mathrm{mM} \mathrm{Fe}$ (III) & $1.12 \pm 0.06$ & $3.89 \pm 0.03$ & $0.76 \pm 0.03$ & $1.90 \pm 0.01$ \\
\hline & $3.47 \mathrm{mM} \mathrm{S}^{0}$ and $6.94 \mathrm{mM} \mathrm{Fe}$ (III) & $3.68 \pm 0.04$ & $3.10 \pm 0.08$ & $0.63 \pm 0.05$ & $1.33 \pm 0.09$ \\
\hline & $3.47 \mathrm{mM} \mathrm{S}^{0}$ and $10.41 \mathrm{mM} \mathrm{Fe}$ (III) & $5.88 \pm 0.09$ & $4.40 \pm 0.01$ & $0.57 \pm 0.01$ & $1.22 \pm 0.06$ \\
\hline & $3.47 \mathrm{mM} \mathrm{Fe}$ (III) & $0.39 \pm 0.08$ & $2.93 \pm 0.03$ & 0 & $2.43 \pm 0.06$ \\
\hline & $3.47 \mathrm{mM} \mathrm{Fe}(\mathrm{III})(\mathrm{wb})$ & $3.29 \pm 0.07$ & $0.17 \pm 0.04$ & 0 & 0 \\
\hline \multirow{9}{*}{$\begin{array}{l}\text { Desulfuromonas sp. } \\
\text { Yavor-7 }\end{array}$} & $3.47 \mathrm{mM} \mathrm{S}^{0}$ & 0 & 0 & $1.84 \pm 0.08$ & $2.32 \pm 0.03$ \\
\hline & $3.47 \mathrm{mM} \mathrm{S}^{0}(\mathrm{wb})$ & 0 & 0 & $0.04 \pm 0.01$ & 0 \\
\hline & $3.47 \mathrm{mM} \mathrm{S}^{0}$ and $1.74 \mathrm{mM} \mathrm{Fe}$ (III) & $0.02 \pm 0.06$ & $1.64 \pm 0.02$ & $0.89 \pm 0.09$ & $2.35 \pm 0.09$ \\
\hline & $3.47 \mathrm{mM} \mathrm{S}^{0}$ and $3.47 \mathrm{mM} \mathrm{Fe}$ (III) & $0.22 \pm 0.05$ & $2.99 \pm 0.09$ & $0.80 \pm 0.01$ & $2.30 \pm 0.06$ \\
\hline & $3.47 \mathrm{mM} \mathrm{S}^{0}$ and $5.21 \mathrm{mM} \mathrm{Fe}$ (III) & $1.61 \pm 0.09$ & $3.49 \pm 0.04$ & $0.73 \pm 0.02$ & $2.00 \pm 0.03$ \\
\hline & $3.47 \mathrm{mM} \mathrm{S}^{0}$ and $6.94 \mathrm{mM} \mathrm{Fe}$ (III) & $3.14 \pm 0.08$ & $3.62 \pm 0.05$ & $0.53 \pm 0.08$ & $1.46 \pm 0.01$ \\
\hline & $3.47 \mathrm{mM} \mathrm{S}^{0}$ and $10.41 \mathrm{mM} \mathrm{Fe}$ (III) & $6.91 \pm 0.04$ & $3.41 \pm 0.06$ & $0.45 \pm 0.06$ & $1.32 \pm 0.05$ \\
\hline & $3.47 \mathrm{mM} \mathrm{Fe}(\mathrm{IIII})$ & $0.42 \pm 0.02$ & $2.87 \pm 0.08$ & 0 & $2.45 \pm 0.07$ \\
\hline & $3.47 \mathrm{mM}$ Fe(III) (wb) & $3.29 \pm 0.07$ & $0.17 \pm 0.04$ & 0 & 0 \\
\hline
\end{tabular}

Note: (wb) - the medium without bacteria. 

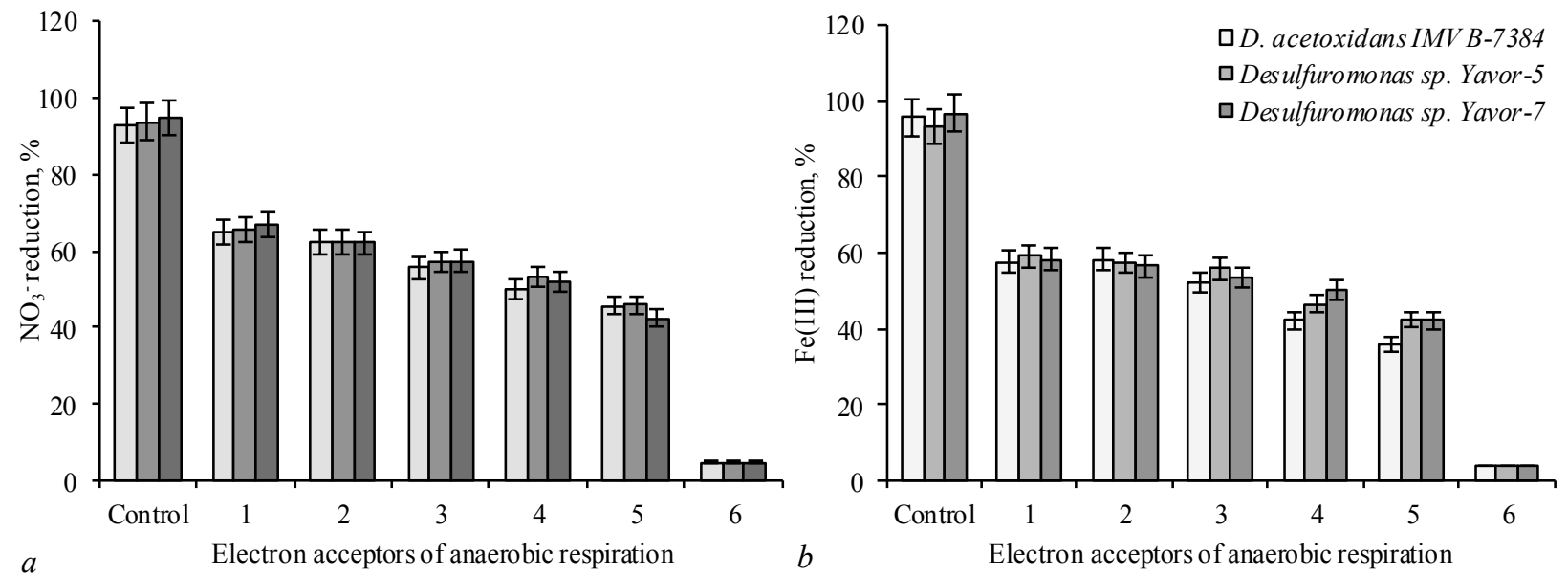

Fig. 2. Efficiency of $\mathrm{NO}^{3-}(a)$ and $\mathrm{Fe}(\mathrm{III})(b)$ reduction by Desulfuromonas sp. after 10 days of growth in media with $\mathrm{NaNO}_{3}$ or $\mathrm{FeC}_{6} \mathrm{H}_{5} \mathrm{O}_{7}$ $(\mathrm{M} \pm \mathrm{m}, \mathrm{n}=3)$ : designation on the horizontal axis: control - $3.47 \mathrm{mM}$ nitrate ions $(a), 3.47 \mathrm{mM} \mathrm{Fe}(\mathrm{III})(b) ; 1-3.47 \mathrm{mM}$ nitrate ions and $1.74 \mathrm{mM}$ $\mathrm{Fe}(\mathrm{III}) ; 2-3.47 \mathrm{mM}$ nitrate ions and $3.47 \mathrm{mM} \mathrm{Fe}(\mathrm{III}) ; 3-3.47 \mathrm{mM}$ nitrate ions and $5.21 \mathrm{mM}$ Fe(III); $4-3.47 \mathrm{mM}$ nitrate ions and $6.94 \mathrm{mM} \mathrm{Fe}(\mathrm{III})$; $5-3.47 \mathrm{mM}$ nitrate ions and $10.41 \mathrm{mM} \mathrm{Fe}(\mathrm{III}) ; 6-3.47 \mathrm{mM}$ nitrate ions (without bacteria) $(a), 3.47 \mathrm{mM} \mathrm{Fe}(\mathrm{III})$ (without bacteria) $(b) ; *_{-} \mathrm{P}<0.05$

Table 2

Reduction of $\mathrm{NO}^{3-}$ and $\mathrm{Fe}(\mathrm{III})$ by Desulfuromonas sp. after 10 days of growth in media with $\mathrm{NaNO}_{3}$ or $\mathrm{FeC}_{6} \mathrm{H}_{5} \mathrm{O}_{7}(\mathrm{M} \pm \mathrm{m}, \mathrm{n}=3)$

\begin{tabular}{|c|c|c|c|c|c|c|}
\hline \multirow{2}{*}{ Strain } & \multirow{2}{*}{$\begin{array}{l}\text { Electron acceptors of anaerobic respira- } \\
\text { tion }\end{array}$} & \multicolumn{2}{|c|}{ Residual content in cultural liquid, $\mathrm{mM}$} & \multirow{2}{*}{$\mathrm{Fe}^{2+}, \mathrm{mM}$} & \multirow{2}{*}{$\mathrm{NH}_{4}^{+}, \mathrm{mM}$} & \multirow{2}{*}{ Biomass, $\mathrm{g} / \mathrm{L}$} \\
\hline & & $\mathrm{NO}_{3}^{-}$ & $\mathrm{Fe}(\mathrm{III})$ & & & \\
\hline \multirow{9}{*}{$\begin{array}{l}\text { D. acetoxidans } \\
\text { IMV B-7384 }\end{array}$} & $3.47 \mathrm{mM} \mathrm{NO}_{3}^{-}$ & $0.25 \pm 0.06$ & 0 & 0 & $1.99 \pm 0.02$ & $2.49 \pm 0.01$ \\
\hline & $3.47 \mathrm{mM} \mathrm{NO}_{3}^{-}(\mathrm{wb})$ & $3.30 \pm 0.03$ & 0 & 0 & $0.15 \pm 0.01$ & 0 \\
\hline & $3.47 \mathrm{mM} \mathrm{NO}_{3}^{-}$and $1.74 \mathrm{mM} \mathrm{Fe}$ (III) & $1.22 \pm 0.04$ & $0.74 \pm 0.03$ & $0.94 \pm 0.01$ & $2.09 \pm 0.05$ & $2.23 \pm 0.03$ \\
\hline & $3.47 \mathrm{mM} \mathrm{NO}_{3}^{-}$and $3.47 \mathrm{mM} \mathrm{Fe}$ (III) & $1.31 \pm 0.08$ & $1.45 \pm 0.02$ & $1.90 \pm 0.02$ & $2.03 \pm 0.01$ & $1.96 \pm 0.05$ \\
\hline & $3.47 \mathrm{mM} \mathrm{NO}_{3}^{-}$and $5.21 \mathrm{mM} \mathrm{Fe}$ (III) & $1.54 \pm 0.01$ & $2.50 \pm 0.05$ & $2.61 \pm 0.02$ & $1.24 \pm 0.08$ & $1.74 \pm 0.01$ \\
\hline & $3.47 \mathrm{mM} \mathrm{NO}_{3}^{-}$and $6.94 \mathrm{mM} \mathrm{Fe}$ (III) & $1.73 \pm 0.02$ & $4.01 \pm 0.08$ & $2.87 \pm 0.06$ & $1.02 \pm 0.01$ & $1.51 \pm 0.01$ \\
\hline & $3.47 \mathrm{mM} \mathrm{NO}_{3}^{-}$and $10.41 \mathrm{mM} \mathrm{Fe}$ (III) & $1.89 \pm 0.03$ & $6.69 \pm 0.01$ & $3.60 \pm 0.04$ & $0.71 \pm 0.03$ & $1.38 \pm 0.02$ \\
\hline & $3.47 \mathrm{mM} \mathrm{Fe}(\mathrm{III})$ & 0 & $0.15 \pm 0.02$ & $3.25 \pm 0.04$ & 0 & $2.65 \pm 0.05$ \\
\hline & $3.47 \mathrm{mM} \mathrm{Fe}(\mathrm{III})(\mathrm{wb})$ & 0 & $3.33 \pm 0.06$ & $0.14 \pm 0.01$ & 0 & 0 \\
\hline \multirow{9}{*}{$\begin{array}{l}\text { Desulfuromonas sp. } \\
\text { Yavor-5 }\end{array}$} & $3.47 \mathrm{mM} \mathrm{NO}_{3}^{-}$ & $0.22 \pm 0.01$ & 0 & 0 & $2.03 \pm 0.06$ & $2.41 \pm 0.03$ \\
\hline & $3.47 \mathrm{mM} \mathrm{NO}_{3}^{-}(\mathrm{wb})$ & $3.30 \pm 0.01$ & 0 & 0 & $0.15 \pm 0.01$ & 0 \\
\hline & $3.47 \mathrm{mM} \mathrm{NO}_{3}^{-}$and $1.74 \mathrm{mM} \mathrm{Fe}$ (III) & $1.19 \pm 0.03$ & $0.71 \pm 0.08$ & $1.00 \pm 0.01$ & $1.91 \pm 0.08$ & $2.32 \pm 0.07$ \\
\hline & $3.47 \mathrm{mM} \mathrm{NO}_{3}^{-}$and $3.47 \mathrm{mM} \mathrm{Fe}$ (III) & $1.31 \pm 0.08$ & $1.48 \pm 0.02$ & $1.84 \pm 0.08$ & $1.89 \pm 0.09$ & $1.96 \pm 0.08$ \\
\hline & $3.47 \mathrm{mM} \mathrm{NO}_{3}^{-}$and $5.21 \mathrm{mM} \mathrm{Fe}$ (III) & $1.49 \pm 0.05$ & $2.30 \pm 0.03$ & $2.82 \pm 0.04$ & $1.31 \pm 0.07$ & $1.63 \pm 0.01$ \\
\hline & $3.47 \mathrm{mM} \mathrm{NO}_{3}^{-}$and $6.94 \mathrm{mM} \mathrm{Fe}$ (III) & $1.62 \pm 0.02$ & $3.71 \pm 0.06$ & $3.07 \pm 0.04$ & $1.08 \pm 0.02$ & $1.45 \pm 0.03$ \\
\hline & $3.47 \mathrm{mM} \mathrm{NO}_{3}^{-}$and $10.41 \mathrm{mM} \mathrm{Fe}(\mathrm{III})$ & $1.88 \pm 0.04$ & $5.99 \pm 0.08$ & $4.34 \pm 0.09$ & $0.82 \pm 0.03$ & $1.30 \pm 0.01$ \\
\hline & $3.47 \mathrm{mM} \mathrm{Fe}(\mathrm{III})$ & 0 & $0.23 \pm 0.04$ & $3.23 \pm 0.02$ & 0 & $2.73 \pm 0.04$ \\
\hline & $3.47 \mathrm{mM} \mathrm{Fe}(\mathrm{III})(\mathrm{wb})$ & 0 & $3.33 \pm 0.05$ & $0.14 \pm 0.01$ & 0 & 0 \\
\hline \multirow{9}{*}{$\begin{array}{l}\text { Desulfurumonas sp. } \\
\text { Yavor-7 }\end{array}$} & $3.47 \mathrm{mM} \mathrm{NO}_{3}^{-}$ & $0.18 \pm 0.01$ & 0 & 0 & $2.00 \pm 0.01$ & $2.32 \pm 0.07$ \\
\hline & $3.47 \mathrm{mM} \mathrm{NO}_{3}^{-}(\mathrm{wb})$ & $3.30 \pm 0.02$ & 0 & 0 & $0.15 \pm 0.01$ & 0 \\
\hline & $3.47 \mathrm{mM} \mathrm{NO}_{3}^{-}$and $1.74 \mathrm{mM} \mathrm{Fe}$ (III) & $1.15 \pm 0.03$ & $0.73 \pm 0.06$ & $0.96 \pm 0.02$ & $2.07 \pm 0.06$ & $2.22 \pm 0.01$ \\
\hline & $3.47 \mathrm{mM} \mathrm{NO}_{3}^{-}$and $3.47 \mathrm{mM} \mathrm{Fe}$ (III) & $1.32 \pm 0.08$ & $1.51 \pm 0.01$ & $1.83 \pm 0.09$ & $1.92 \pm 0.04$ & $1.94 \pm 0.03$ \\
\hline & $3.47 \mathrm{mM} \mathrm{NO}_{3}{ }^{-}$and $5.21 \mathrm{mM} \mathrm{Fe}$ (III) & $1.48 \pm 0.09$ & $2.43 \pm 0.02$ & $2.68 \pm 0.04$ & $1.49 \pm 0.05$ & $1.71 \pm 0.05$ \\
\hline & $3.47 \mathrm{mM} \mathrm{NO}_{3}^{-}$and $6.94 \mathrm{mM} \mathrm{Fe}$ (III) & $1.66 \pm 0.06$ & $3.47 \pm 0.02$ & $3.30 \pm 0.05$ & $1.15 \pm 0.08$ & $1.59 \pm 0.08$ \\
\hline & $3.47 \mathrm{mM} \mathrm{NO}_{3}^{-}$and $10.41 \mathrm{mM} \mathrm{Fe}$ (III) & $2.00 \pm 0.03$ & $6.03 \pm 0.03$ & $4.36 \pm 0.06$ & $0.79 \pm 0.01$ & $1.32 \pm 0.01$ \\
\hline & $3.47 \mathrm{mM}$ Fe(III) & 0 & $0.11 \pm 0.08$ & $3.28 \pm 0.08$ & 0 & $2.67 \pm 0.02$ \\
\hline & $3.47 \mathrm{mM} \mathrm{Fe}(\mathrm{III})(\mathrm{wb})$ & 0 & $3.33 \pm 0.07$ & $0.14 \pm 0.01$ & 0 & 0 \\
\hline
\end{tabular}

Notes: (wb) - the medium without bacteria; to the media with $\mathrm{NO}_{3}{ }^{-}$and $\mathrm{Fe}(\mathrm{III})$ or without it the $\mathrm{NH}_{4} \mathrm{Cl}$ was not added.

To study the influence of ferrum (III) citrate on the nitrate ions reduction by sulfur reducing bacteria, they were cultivated in the medium without $\mathrm{NH}_{4} \mathrm{Cl}$ with sodium citrate, to which $3.47 \mathrm{mM} \mathrm{NaNO}_{3}$ and $\mathrm{FeC}_{6} \mathrm{H}_{5} \mathrm{O}_{7}$ at different concentrations were added. The bacteria were also grown in media with sodium citrate and $3.47 \mathrm{mM} \mathrm{NaNO}_{3}$ or $3.47 \mathrm{mM} \mathrm{FeC}_{6} \mathrm{H}_{5} \mathrm{O}_{7}$ to test the usage by bacteria of nitrate ions or $\mathrm{Fe}(\mathrm{III})$ as the sole electron acceptor (Table 2). After 10 days of growth, the biomass of bacteria in the medium with $\mathrm{NaNO}_{3}$ was revealed to be1.1-1.2 times lower than in the medium with $\mathrm{FeC}_{6} \mathrm{H}_{5} \mathrm{O}_{7}$. After simultaneous addition of $\mathrm{NaNO}_{3}$ and $\mathrm{FeC}_{6} \mathrm{H}_{5} \mathrm{O}_{7}$ to the medium with increasing of ferrum (III) citrate concentrations, a gradual inhibition of bacteria growth was observed, compared with growth in the medium with only $\mathrm{NaNO}_{3}$ or $\mathrm{FeC}_{6} \mathrm{H}_{5} \mathrm{O}_{7}$. In the medium with $\mathrm{NaNO}_{3}$ and $10.41 \mathrm{mM} \mathrm{FeC}_{6} \mathrm{H}_{5} \mathrm{O}_{7}$ the growth of bacteria decreased 1.8-2.1 times, compared with the growth in the medium with $\mathrm{NaNO}_{3}$ or $\mathrm{FeC}_{6} \mathrm{H}_{5} \mathrm{O}_{7}$ as the sole electron acceptor. In the media with $\mathrm{NaNO}_{3}$ and $\mathrm{FeC}_{6} \mathrm{H}_{5} \mathrm{O}_{7}$ with increasing of ferrum (III) citrate concentrations a gradual (1.4-2.2 times) decrease of the efficiency of nitrate ions reduction by bacteria was also observed, compared with their reduction in the medium with only $\mathrm{NaNO}_{3}(92.7-94.8 \%$ ) (Fig. 2a). In the medium with $\mathrm{NaNO}_{3}$ and $\mathrm{FeC}_{6} \mathrm{H}_{5} \mathrm{O}_{7}$, bacteria produced $0.71-2.09 \mathrm{mM}$ of ammonium ions (control: 1.99-2.03 mM, Table 2). The efficiency of Fe(III) reduction by cells with increasing its concentrations in media with $\mathrm{NaNO}_{3}$ and $\mathrm{FeC}_{6} \mathrm{H}_{5} \mathrm{O}_{7}$ was revealed to be 1.6-2.7 times lower than their reduction in medium with only $\mathrm{FeC}_{6} \mathrm{H}_{5} \mathrm{O}_{7}$ (93.4-96.8\%) (Fig. 2b). In media with $\mathrm{NaNO}_{3}$ and $\mathrm{FeC}_{6} \mathrm{H}_{5} \mathrm{O}_{7}$, bacteria produced $0.94-4.36 \mathrm{mM}$ of ferrum (II) ions (control: $3.23-3.28 \mathrm{mM}$, Table 2). In the medium with $\mathrm{NaNO}_{3}$ or $\mathrm{FeC}_{6} \mathrm{H}_{5} \mathrm{O}_{7}$ without bacteria, the efficiency of $\mathrm{NO}^{3-}$ and $\mathrm{Fe}(\mathrm{III})$ reduction did not exceed $4.8 \%$ and $4.0 \%$, respectively (Fig. 2). Thus, it has been shown that ferrum (III) citrate inhibits the biomass accumulation, the nitrate ions reduction and the ammonium ions production by bacteria of Desulfuromonas sp. after simultaneous addition into the medium of $3.47 \mathrm{mM} \mathrm{NaNO}_{3}$ and 1.74-10.41 $\mathrm{mM} \mathrm{FeC}_{6} \mathrm{H}_{5} \mathrm{O}_{7}$. In the medium with the same initial content $(3.47 \mathrm{mM})$ of $\mathrm{NaNO}_{3}$ and $\mathrm{FeC}_{6} \mathrm{H}_{5} \mathrm{O}_{7}$ bacteria produced ammonium ions at concentrations 1.1 times higher than that of ferrum (II) ions. 

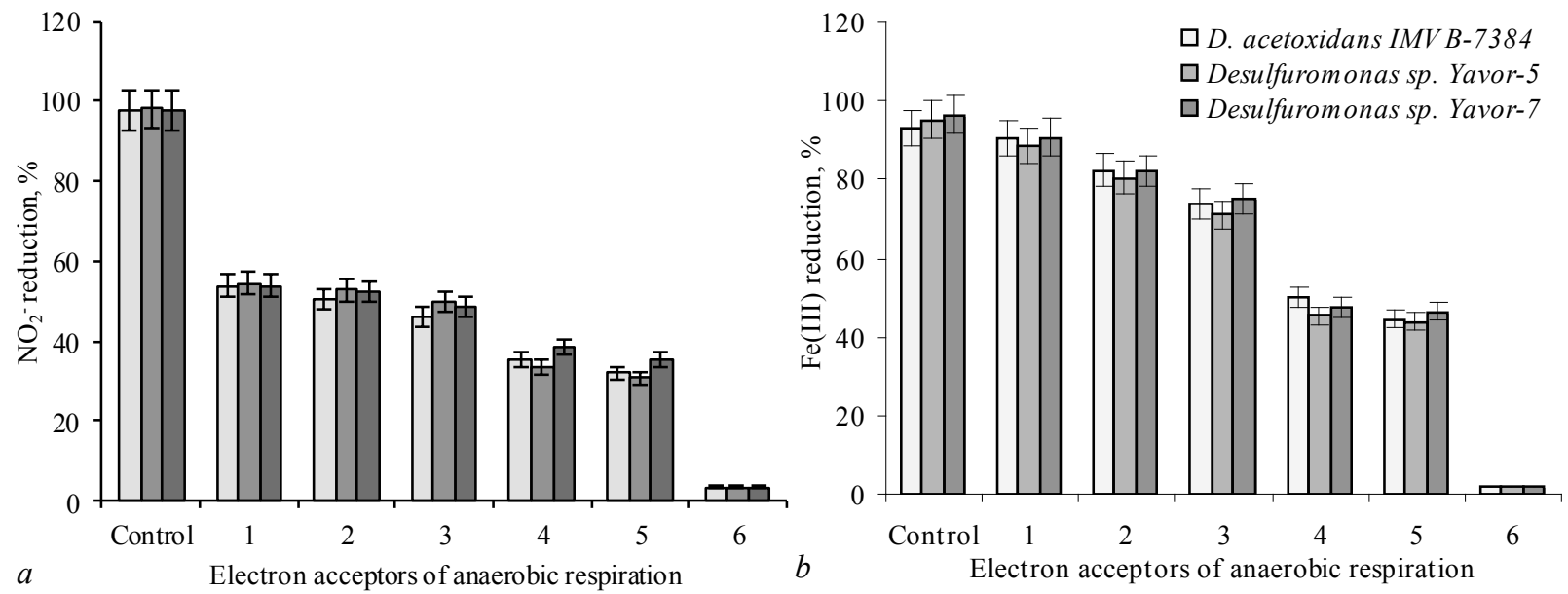

Fig. 3. Efficiency of $\mathrm{NO}_{2}^{-}(a)$ and $\mathrm{Fe}(\mathrm{III})(b)$ reduction by Desulfuromonas sp. after 10 days of growth in media with $\mathrm{NaNO}_{2}$ or $\mathrm{FeC}_{6} \mathrm{H}_{5} \mathrm{O}_{7}$ $(\mathrm{M} \pm \mathrm{m}, \mathrm{n}=3)$ : designation on the horizontal axis: control $-3.47 \mathrm{mM}$ nitrite ions $(a), 3.47 \mathrm{mM} \mathrm{Fe}(\mathrm{III})(b) ; 1-3.47 \mathrm{mM}$ nitrite ions and $1.74 \mathrm{mM}$ $\mathrm{Fe}(\mathrm{III}) ; 2-3.47 \mathrm{mM}$ nitrite ions and $3.47 \mathrm{mM} \mathrm{Fe}$ (III); $3-3.47 \mathrm{mM}$ nitrite ions and $5.21 \mathrm{mM} \mathrm{Fe}(\mathrm{III}) ; 4-3.47 \mathrm{mM}$ nitrite ions and $6.94 \mathrm{mM} \mathrm{Fe}(\mathrm{IIII})$; $5-3.47 \mathrm{mM}$ nitrite ions and $10.41 \mathrm{mM} \mathrm{Fe}(\mathrm{III}) ; 6-3.47 \mathrm{mM}$ nitrite ions (without bacteria) (a), $3.47 \mathrm{mM} \mathrm{Fe}(\mathrm{III})$ (without bacteria) $(b) ;{ }^{*}-\mathrm{P}<0.05$

Table 3

Reduction of $\mathrm{NO}_{2}^{-}$and $\mathrm{Fe}(\mathrm{III})$ by Desulfuromonas sp. after 10 days of growth in media with $\mathrm{NaNO}_{2}$ or $\mathrm{FeC}_{6} \mathrm{H}_{5} \mathrm{O}_{7}(\mathrm{M} \pm \mathrm{m}, \mathrm{n}=3)$

\begin{tabular}{|c|c|c|c|c|c|c|}
\hline \multirow{2}{*}{ Strain } & \multirow{2}{*}{$\begin{array}{c}\text { Electron acceptors } \\
\text { of anaerobic respiration }\end{array}$} & \multicolumn{2}{|c|}{ Residual content in cultural liquid, $\mathrm{mM}$} & \multirow{2}{*}{$\mathrm{Fe}^{2+}, \mathrm{mM}$} & \multirow{2}{*}{$\mathrm{NH}_{4}^{+}, \mathrm{mM}$} & \multirow{2}{*}{ Biomass, g/L } \\
\hline & & $\mathrm{NO}_{2}^{-}$ & $\mathrm{Fe}(\mathrm{III})$ & & & \\
\hline \multirow{9}{*}{$\begin{array}{l}\text { D. acetoxidans } \\
\text { IMV B-7384 }\end{array}$} & $3.47 \mathrm{mM} \mathrm{NO}_{2}^{-}$ & $0.08 \pm 0.03$ & 0 & 0 & $2.02 \pm 0.03$ & $2.32 \pm 0.02$ \\
\hline & $3.47 \mathrm{mM} \mathrm{NO}_{2}^{-}(\mathrm{wb})$ & $3.35 \pm 0.07$ & 0 & 0 & $0.09 \pm 0.05$ & 0 \\
\hline & $3.47 \mathrm{mM} \mathrm{NO}_{2}^{-}$and $1.74 \mathrm{mM} \mathrm{Fe}(\mathrm{III})$ & $1.60 \pm 0.09$ & $0.17 \pm 0.01$ & $1.46 \pm 0.02$ & $1.74 \pm 0.04$ & $2.26 \pm 0.03$ \\
\hline & $3.47 \mathrm{mM} \mathrm{NO}_{2}^{-}$and $3.47 \mathrm{mM} \mathrm{Fe}$ (III) & $1.71 \pm 0.01$ & $0.61 \pm 0.03$ & $2.77 \pm 0.01$ & $1.60 \pm 0.01$ & $2.12 \pm 0.05$ \\
\hline & $3.47 \mathrm{mM} \mathrm{NO}_{2}^{-}$and $5.21 \mathrm{mM} \mathrm{Fe}(\mathrm{III})$ & $1.87 \pm 0.02$ & $1.37 \pm 0.07$ & $3.71 \pm 0.03$ & $1.01 \pm 0.08$ & $1.70 \pm 0.02$ \\
\hline & $3.47 \mathrm{mM} \mathrm{NO}_{2}^{-}$and $6.94 \mathrm{mM} \mathrm{Fe}$ (III) & $2.25 \pm 0.03$ & $3.48 \pm 0.01$ & $3.34 \pm 0.05$ & $0.83 \pm 0.02$ & $1.44 \pm 0.01$ \\
\hline & $3.47 \mathrm{mM} \mathrm{NO}_{2}^{-}$and $10.41 \mathrm{mM} \mathrm{Fe}$ (III) & $2.36 \pm 0.07$ & $5.79 \pm 0.02$ & $4.58 \pm 0.04$ & $0.55 \pm 0.03$ & $1.11 \pm 0.03$ \\
\hline & 3.47 mM Fe(III) & 0 & $0.24 \pm 0.03$ & $3.17 \pm 0.07$ & 0 & $2.74 \pm 0.04$ \\
\hline & $3.47 \mathrm{mM} \mathrm{Fe}(\mathrm{III})(\mathrm{wb})$ & 0 & $3.40 \pm 0.09$ & $0.07 \pm 0.04$ & 0 & 0 \\
\hline \multirow{9}{*}{$\begin{array}{l}\text { Desulfuromonas sp. } \\
\text { Yavor-5 }\end{array}$} & $3.47 \mathrm{mM} \mathrm{NO}_{2}^{-}$ & $0.07 \pm 0.02$ & 0 & 0 & $2.00 \pm 0.07$ & $2.30 \pm 0.09$ \\
\hline & $3.47 \mathrm{mM} \mathrm{NO}_{2}^{-}(\mathrm{wb})$ & $3.35 \pm 0.07$ & 0 & 0 & $0.09 \pm 0.05$ & 0 \\
\hline & $3.47 \mathrm{mM} \mathrm{NO}_{2}^{-}$and $1.74 \mathrm{mM} \mathrm{Fe}(\mathrm{III})$ & $1.58 \pm 0.04$ & $0.20 \pm 0.01$ & $1.38 \pm 0.06$ & $1.70 \pm 0.02$ & $2.21 \pm 0.01$ \\
\hline & $3.47 \mathrm{mM} \mathrm{NO}_{2}^{-}$and $3.47 \mathrm{mM} \mathrm{Fe}$ (III) & $1.64 \pm 0.06$ & $0.68 \pm 0.03$ & $2.60 \pm 0.04$ & $1.54 \pm 0.01$ & $2.09 \pm 0.02$ \\
\hline & $3.47 \mathrm{mM} \mathrm{NO}_{2}^{-}$and $5.21 \mathrm{mM} \mathrm{Fe}$ (III) & $1.75 \pm 0.01$ & $1.51 \pm 0.01$ & $3.60 \pm 0.01$ & $1.00 \pm 0.03$ & $1.73 \pm 0.03$ \\
\hline & $3.47 \mathrm{mM} \mathrm{NO}_{2}^{-}$and $6.94 \mathrm{mM} \mathrm{Fe}$ (III) & $2.31 \pm 0.02$ & $3.78 \pm 0.04$ & $3.02 \pm 0.02$ & $0.87 \pm 0.01$ & $1.40 \pm 0.03$ \\
\hline & $3.47 \mathrm{mM} \mathrm{NO}_{2}^{-}$and $10.41 \mathrm{mM} \mathrm{Fe}$ (III) & $2.40 \pm 0.04$ & $5.86 \pm 0.05$ & $4.48 \pm 0.01$ & $0.58 \pm 0.02$ & $1.15 \pm 0.05$ \\
\hline & 3.47 mM Fe(III) & 0 & $0.17 \pm 0.09$ & $3.24 \pm 0.03$ & 0 & $2.70 \pm 0.01$ \\
\hline & $3.47 \mathrm{mM} \mathrm{Fe}(\mathrm{III})(\mathrm{wb})$ & 0 & $3.40 \pm 0.09$ & $0.07 \pm 0.04$ & 0 & 0 \\
\hline \multirow{9}{*}{$\begin{array}{l}\text { Desulfurumonas sp. } \\
\text { Yavor-7 }\end{array}$} & $3.47 \mathrm{mM} \mathrm{NO}_{2}^{-}$ & $0.08 \pm 0.08$ & 0 & 0 & $2.05 \pm 0.01$ & $2.32 \pm 0.07$ \\
\hline & $3.47 \mathrm{mM} \mathrm{NO}_{2}^{-}(\mathrm{wb})$ & $3.35 \pm 0.07$ & 0 & 0 & $0.09 \pm 0.05$ & 0 \\
\hline & $3.47 \mathrm{mM} \mathrm{NO}_{2}^{-}$and $1.74 \mathrm{mM} \mathrm{Fe}$ (III) & $1.60 \pm 0.02$ & $0.16 \pm 0.07$ & $1.40 \pm 0.07$ & $1.71 \pm 0.01$ & $2.28 \pm 0.02$ \\
\hline & $3.47 \mathrm{mM} \mathrm{NO}_{2}^{-}$and $3.47 \mathrm{mM} \mathrm{Fe}$ (III) & $1.66 \pm 0.03$ & $0.62 \pm 0.03$ & $2.64 \pm 0.01$ & $1.59 \pm 003$ & $2.11 \pm 0.03$ \\
\hline & $3.47 \mathrm{mM} \mathrm{NO}_{2}^{-}$and $5.21 \mathrm{mM} \mathrm{Fe}$ (III) & $1.79 \pm 0.01$ & $1.30 \pm 0.04$ & $3.78 \pm 0.02$ & $1.02 \pm 0.01$ & $1.68 \pm 0.07$ \\
\hline & $3.47 \mathrm{mM} \mathrm{NO}_{2}^{-}$and $6.94 \mathrm{mM} \mathrm{Fe}$ (III) & $2.13 \pm 0.04$ & $3.64 \pm 0.01$ & $3.26 \pm 0.01$ & $0.80 \pm 0.02$ & $1.42 \pm 0.05$ \\
\hline & $3.47 \mathrm{mM} \mathrm{NO}_{2}^{-}$and $10.41 \mathrm{mM} \mathrm{Fe}$ (III) & $2.25 \pm 0.04$ & $5.58 \pm 0.03$ & $4.69 \pm 0.03$ & $0.54 \pm 0.01$ & $1.12 \pm 0.01$ \\
\hline & 3.47 mM Fe(III) & 0 & $0.12 \pm 0.01$ & $3.25 \pm 0.07$ & 0 & $2.77 \pm 0.02$ \\
\hline & $3.47 \mathrm{mM} \mathrm{Fe}(\mathrm{III})(\mathrm{wb})$ & 0 & $3.40 \pm 0.09$ & $0.07 \pm 0.04$ & 0 & 0 \\
\hline
\end{tabular}

Notes: (wb) - the medium without bacteria; to the media with $\mathrm{NO}_{3}^{-}$and $\mathrm{Fe}(\mathrm{III})$ or without it the $\mathrm{NH}_{4} \mathrm{Cl}$ was not added.

To investigate the influence of ferrum (III) citrate on the nitrite ions reduction by sulfur reducing bacteria, they were grown in the medium without $\mathrm{NH}_{4} \mathrm{Cl}$ with sodium citrate to which $3.47 \mathrm{mM} \mathrm{NaNO} 2$ and $\mathrm{FeC}_{6} \mathrm{H}_{5} \mathrm{O}_{7}$ at different concentrations were added. The bacteria were also sown in media with sodium citrate and $3.47 \mathrm{mM} \mathrm{NaNO}_{2}$ or $3.47 \mathrm{mM} \mathrm{FeC}_{6} \mathrm{H}_{5} \mathrm{O}_{7}$ to study the usage by bacteria of nitrite ions or $\mathrm{Fe}(\mathrm{III})$ as the sole electron acceptor (Table 3). Biomass of bacteria in the medium with only $\mathrm{NaNO}_{2}$ was revealed to be 1.2 times lower than in the medium with only $\mathrm{FeC}_{6} \mathrm{H}_{5} \mathrm{O}_{7}$. After simultaneous addition into the medium of $\mathrm{NaNO}_{2}$ and $\mathrm{FeC}_{6} \mathrm{H}_{5} \mathrm{O}_{7}$ with increasing concentrations of the ferrum (III) citrate, a decrease in the bacteria growth was observed, compared with growth in the medium with only $\mathrm{NaNO}_{2}$ or $\mathrm{FeC}_{6} \mathrm{H}_{5} \mathrm{O}_{7}$. In the medium with $\mathrm{NaNO}_{2}$ and $10.41 \mathrm{mM}$ $\mathrm{FeC}_{6} \mathrm{H}_{5} \mathrm{O}_{7}$, the growth of bacteria was decreased 2.0-2.5 times, compared with growth in the medium with $\mathrm{NaNO}_{2}$ or $\mathrm{FeC}_{6} \mathrm{H}_{5} \mathrm{O}_{7}$ as the sole electron acceptor. In media with $\mathrm{NaNO}_{2}$ and $\mathrm{FeC}_{6} \mathrm{H}_{5} \mathrm{O}_{7}$ with increasing concentrations of the ferrum (III) citrate there was a gradual decrease (1.8-3.2 times) of the efficiency of nitrite ions reduction by bacteria, as compared with their reduction in the medium with only $\mathrm{NaNO}_{2}(97.7-98.0 \%$, Fig. 3a). In media, containing $\mathrm{NaNO}_{2}$ and $\mathrm{FeC}_{6} \mathrm{H}_{5} \mathrm{O}_{7}$, the cells produced 0.54 $1.74 \mathrm{mM}$ of ammonium ions (control: $2.00-2.05 \mathrm{mM}$, Table 3 ). The efficiency of the Fe(III) reduction by bacteria with increase in its concentration in media with $\mathrm{NaNO}_{2}$ and $\mathrm{FeC}_{6} \mathrm{H}_{5} \mathrm{O}_{7}$ was revealed to be 1.1-2.2 times lower than its reduction in medium with only $\mathrm{FeC}_{6} \mathrm{H}_{5} \mathrm{O}_{7}(93.1-96.5 \%$, Fig. 3b). In the media with $\mathrm{NaNO}_{2}$ and $\mathrm{FeC}_{6} \mathrm{H}_{5} \mathrm{O}_{7}$ cells produced $1.38-4.69 \mathrm{mM}$ of the ferrum (II) ions (control: 3.17-3.25 mM, Table 3). In the medium with $\mathrm{NaNO}_{2}$ or $\mathrm{FeC}_{6} \mathrm{H}_{5} \mathrm{O}_{7}$ without bacteria the reduction of $\mathrm{NO}^{2-}$ and Fe(III) did not exceed $3.5 \%$ and $2.0 \%$, respectively (Fig. 3). Thus, it has been established that ferrum (III) citrate inhibits the biomass accumulation, the nitrite ions reduction and the ammonium ions production by bacteria of Desulfuromonas sp. after simultaneous addition into the medium of $3.47 \mathrm{mM}$ $\mathrm{NaNO}_{2}$ and 1.74-10.41 mM FeC $\mathrm{H}_{5} \mathrm{O}_{7}$. In the medium with the same initial content $(3.47 \mathrm{mM}) \mathrm{NaNO}_{2}$ and $\mathrm{FeC}_{6} \mathrm{H}_{5} \mathrm{O}_{7}$, bacteria reduced 1.51.6 times more $\mathrm{Fe}$ (III) than nitrite ions with production of ferrum (II) ions at a concentration 1.7 times higher than that of ammonium ions. 


\section{Discussion}

The efficiency of reduction of electron acceptors by microorganisms in ecotopes with complex contamination is determined by the level of their adaptation to unfavourable environmental conditions, in particular, the increased content of metal compounds (Teng et al., 2019). Therefore, the ability of bacteria of Desulfuromonas sp. to reduce sulfur, nitrate or nitrite ions in the process of anaerobic respiration at a simultaneous presence in the medium of $\mathrm{FeC}_{6} \mathrm{H}_{5} \mathrm{O}_{7}$ at concentrations up to $10.41 \mathrm{mM}$, which exceed the maximum admissible norms, was studied (Kuznetsov et al., 2015).

The efficiency of electron acceptor reduction by bacteria is primarily determined by the difference between the oxidation-reduction potential of the donor (in this work, sodium citrate) and the electron acceptor, which depends on the $\mathrm{pH}$ of the medium and changes during cultivation of bacteria (Govorukha et al., 2015). Sulfur-reducing bacteria of the Desulfuromonas genus oxidize organic substrates, in particular, acetate, pyruvate, ethanol, butanol, propanol, lactate, citrate, propionate, glutamate, higher fatty acids completely to $\mathrm{CO}_{2}$ and $\mathrm{H}_{2} \mathrm{O}$ in the tricarboxylic acid cycle or in the acetyl-CoA/CO-dehydrogenase pathway (Sung et al., 2003; An \& Picarda, 2015), among them are species able to ferment Lmalate or fumarate with or without acetate by action of fumarate reductase (or succinate dehydrogenase) (Gebhardt et al., 1985; Lemos et al., 2002; Lengeler et al., 2005). Although the succession of electron acceptors reduction by microorganisms at their simultaneous presence in the medium is determined by their standard oxidation-reduction potential ( $\mathrm{pH} 7.0)$, the energy supply of cells during anaerobic respiration depends on the ways of ATP synthesis in the process of electron donor oxidation.

At simultaneous presence in the cultivation medium of sulfur and $\mathrm{Fe}$ (III) citrate, bacteria reduce more $\mathrm{Fe}(\mathrm{III})$ than $\mathrm{S}^{0}$ (at $\mathrm{pH}$ 7.0) the standard oxidation-reduction potential $\left(\mathrm{E}_{0}{ }^{\prime}=+0.77 \mathrm{~V}\right)$ of the $\mathrm{Fe}(\mathrm{III}) / \mathrm{Fe}$ (II) pair is considerably higher than that $\left(\mathrm{E}_{0}{ }^{\prime}=-0,27 \mathrm{~V}\right)$ of $\mathrm{S}^{0} / \mathrm{HS}^{-}$pair $)$ (Lengeler et al., 2005; An \& Picarda, 2015). The evidence of this is the fact that in the medium with the same initial concentration $(3.47 \mathrm{mM})$ of $\mathrm{S}^{0}$ and $\mathrm{FeC}_{6} \mathrm{H}_{5} \mathrm{O}_{7}$ the content of $\mathrm{H}_{2} \mathrm{~S}$ was 3.5-3.9 times lower than the content of ferrum (II) ions, produced by bacteria. In the sulfur respiration of bacteria of Desulfuromonas genus sulfur reductase and polysufide reductase are involved, which are located in the cytoplasmic membrane and bonded with hydrogenase by cytochromes or quinones (Lengeler et al., 2005). Ferrum (III) citrate at all tested concentrations in the medium represses the dissimilatory sulfur reduction carried out by bacteria, as evidenced by the decrease in the concentrations of hydrogen sulfide produced by bacteria in the media with $\mathrm{S}^{0}$ and $\mathrm{FeC}_{6} \mathrm{H}_{5} \mathrm{O}_{7}$. Under these conditions of growth, ferrum (III) cations, chelated by citrate, may damage the structure of the cytoplasmic membrane of bacteria and thus influence the activity of membrane bound enzymes (Maslovska \& Hnatush, 2013; Maslovska et al., 2014). Although the reduction of metalsoxidants by membrane-bound metal reductases is mainly carried out outside the cell (Gescher \& Kappler, 2012; Richter et al., 2012; Simonte et al., 2017), with increase in the concentration of soluble $\mathrm{FeC}_{6} \mathrm{H}_{5} \mathrm{O}_{7}$ in the medium the degree of $\mathrm{Fe}(\mathrm{III})$ penetration through the cytoplasmic membrane of bacteria into the cytoplasm increases, where its interaction with intracellular metabolites occurs, oxygen radicals are formed, which causes the inhibition of growth and metabolic activity of bacteria (Hnatush \& Maslovska, 2018).

At $\mathrm{pH} 7.0$ the standard oxidation-reduction potential of the $\mathrm{Fe}(\mathrm{III}) / \mathrm{Fe}$ (II) pair $\left(\mathrm{E}_{0}{ }^{\prime}=+0.77 \mathrm{~V}\right)$ is lower than that of $\mathrm{NO}_{3}{ }^{-} / \mathrm{NO}_{2}{ }^{-}$pair $\left(\mathrm{E}_{0}{ }^{\prime}=+0.78 \mathrm{~V}\right)$, but higher than that of $\mathrm{NO}_{2}{ }^{-} / \mathrm{NH}_{4}{ }^{+}$pair $\left(\mathrm{E}_{0}{ }^{\prime}=+0.34 \mathrm{~V}\right)$ (Lengeler et al., 2005; Richter et al., 2012). In the medium with the same initial content $(3.47 \mathrm{mM})$ of $\mathrm{NaNO}_{3}$ and $\mathrm{FeC}_{6} \mathrm{H}_{5} \mathrm{O}_{7}$, bacteria did not reduce many more nitrate ions than $\mathrm{Fe}(\mathrm{III})$, and in the medium with the same content $(3.47 \mathrm{mM})$ of $\mathrm{NaNO}_{2}$ and $\mathrm{FeC}_{6} \mathrm{H}_{5} \mathrm{O}_{7}$ the strains reduced 1.5-1.6 times more $\mathrm{Fe}$ (III) than nitrite ions. Nevertheless, $\mathrm{FeC}_{6} \mathrm{H}_{5} \mathrm{O}_{7}$ at all concentrations in the medium inhibited the nitrate and nitrite reduction, which was carried out by the investigated strains of bacteria. The process of nitrate reduction carried out by bacteria of $D e-$ sulfuromonas genus was less sensitive to the negative influence of $\mathrm{FeC}_{6} \mathrm{H}_{5} \mathrm{O}_{7}$, compared to the process of nitrite ions reduction. When the reduction of nitrate ions by bacteria in the presence of $1.74-10.41 \mathrm{mM}$ $\mathrm{FeC}_{6} \mathrm{H}_{5} \mathrm{O}_{7}$ decreased 1.4-2.2 times, then the reduction of nitrite ions de- creased 1.8-3.2 times, compared to their reduction in the media with only $\mathrm{NaNO}_{3}$ or $\mathrm{NaNO}_{2}$, respectively. The negative influence of ferrum (III) citrate on the activity of molybdenum-containing membrane-bound respiratory or dissimilatory nitrate reductase (Morozkina \& Zvyagilskaya, 2007), as well as periplasmic nitrite reductase, containing siro heme as a prosthetic group (Lengeler et al., 2005), in bacteria of Desulfuromonas genus can be caused by damage of the cytoplasmic membrane structure or modification of the active conformation and denaturation of the protein molecule as a result of the replacement by ferrum of the necessary metal ion in the active centre of the enzyme.

Despite the fact that the reduction of Fe(III) by cells in media with 1.74-10.41 $\mathrm{mM} \mathrm{FeC}_{6} \mathrm{H}_{5} \mathrm{O}_{7}$ and $3.47 \mathrm{mM} \mathrm{S}^{0}, \mathrm{NaNO}_{3}$ or $\mathrm{NaNO}_{2}$ decreased 1.6-2.7, 1.6-2.7 and 1.1-2.2 times, respectively, compared with its reduction in medium with only $\mathrm{FeC}_{6} \mathrm{H}_{5} \mathrm{O}_{7}$ as the sole electron acceptor, the results obtained by us suggest that the investigated strains of bacteria are resistant to high concentrations of trivalent ferrum compounds (up to $10.41 \mathrm{mM}$ ) and therefore can survive in environments contaminated by heavy metals. The studied strains are promising for use in technologies of complex purification of the environment polluted by ferrum and nitrogen compounds due to their ability to effect reductive transformation of these toxicants.

\section{Conclusion}

Because of the long-term entry into the environment of various chemical contaminants at critical concentrations, the metabolism of bacteria slows down, the species composition of microbiocenoses changes, and in the process of natural selection few resistant strains of microorganisms survive. Sulfidogenic bacteria of the Desulfuromonas genus, isolated by us from the technogenically formed Yavorivske Lake, in the process of organic compounds oxidation use, besides sulfur, oxidized forms of nitrogen and heavy metals, in particular, ferrum (III) as electron acceptors of anaerobic respiration. In media with elemental sulfur or sodium nitrite $(3.47 \mathrm{mM})$ and ferrum (III) citrate $(1.74-10.41 \mathrm{mM})$ bacteria reduced more $\mathrm{Fe}(\mathrm{III})$ than $\mathrm{S}^{0}$ or $\mathrm{NO}_{2}^{-}$. In media with $3.47 \mathrm{mM}$ sodium nitrate and $1.74-10.41 \mathrm{mM}$ ferrum (III) citrate bacteria reduced more $\mathrm{NO}_{3}^{-}$than $\mathrm{Fe}(\mathrm{III})$. Despite this, ferrum (III) citrate at all concentrations in the medium inhibited the dissimilatory sulfur, nitrate and nitrite reduction carried out by bacteria. Due to the high plasticity of the processes of metabolism adapted to survival conditions, bacteria of Desulfuromonas sp. can be the basis of the new developments in the field of ecobiotechnology.

\section{References}

An, T. T., \& Picarda, F. W. (2015). Desulfuromonas carbonis sp. nov., an Fe (III)-, $\mathrm{S}^{0}$ and $\mathrm{Mn}$ (IV)-reducing bacterium isolated from an active coalbed methane gas well. International Journal of Systematic and Evolutionary Microbiology, 65(5), 1686-1693.

Baran, I. M., Podopryhora, O. I., Gryshchuk, G. V., Bondar, L. S., Kit, L. Y., Klym, I. R., Hnatush, S. O., \& Gudz, S. P. (2003). Ekolohichnyy monitorynh vodoym Yavorivs'koho sirkovoho rodovyshcha; mikrobiolohichnyy kontrol' [The ecological monitoring of Yavoriv sulfur deposit reservoirs; microbiological control]. Environment and Health, 27(4), 56-62 (in Ukrainian).

Bilyy, O. I., Vasyliv, O. M., \& Hnatush, S. O. (2014). The anode biocatalyst with simultaneous transition metals pollution control. In: Technology and application of microbial fuel cells. InTech, Rijeka.

Bokranz, M. J., Katz, J., Schröder, I., Roberton, A. M., \& Kröger, A. (1983). Energy metabolism and biosynthesis of Vibrio succinogenes growing with nitrate or nitrite as terminal electron acceptor. Archives of Microbiology, 135, 36-41.

Breuer, M., Rosso, K. M., Blumberger, J., \& Butt, J. N. (2015). Multi-haem cytochromes in Shewanella oneidensis MR-1: Structures, functions and opportunities. Journal of the Royal Society Interface, 12(102), 1117.

Chayka, O. M., \& Peretyatko, T. B. (2018). The reduction of hexavalent chromium and nitrates by Desulfuromonas sp. YSDS-3, isolated from the soil of Yasiv sulfur mine. Ecology and Noospherology, 29(2), 76-82.

Fitzgerald, L. A., Petersen, E. R., Leary, D. H., Nadeau, L. J., Soto, C. M., Ray, R. I., Little, B. J., Ringeisen, B. R., Johnson, G. R., Vora, G. J., \& Biffinger, J. C. (2013). Shewanella frigidimarina microbial fuel cells and the influence of divalent cations on current output. Biosensors and Bioelectronics, 40(1), 102-109.

Gaidin, A. M., \& Zozulia, I. I. (2009). Novi ozera Lvivshchyny [New lakes of Lviv region]. Afisha, Lviv (in Ukrainian). 
Gebhardt, N. A.,Thauer, R. K., Linder, D., Kaulfers, P.-M., \& Pfennig, N. (1985). Mechanism of acetate oxidation to $\mathrm{CO}_{2}$ with elemental sulfur in Desulfuromonas acetoxidans. Archives of Microbiology, 141, 392-398.

Gescher, J., \& Kappler, A. (2012). Microbial metal respiration: From geochemistry to potential applications. Springer-Verlag, Heidelberg.

Govorukha, V. M., Havrylyuk, O. A., \& Tashyrev, O. B. (2015). Regularities of quantitative distribution for $\mathrm{Fe}(\mathrm{III})$-reducing bacteria in natural ecosystems. Biotechnologia Acta, 8(3), 123-128.

Granger, D. L., Taintor, R. R., Boockvar, K. S., \& Hibbs, J. B. (1996). Measurement of nitrate and nitrite in biological samples using nitrate reductase and Griess reaction. Methods Enzymology, 268, 142-151.

Gudz, S. P., Hnatush, S. O., Moroz, O. M., Peretiatko, T. B., \& Vasyliv, O. M (2013). Svidotstvo pro deponuvannya shtamu bakteriy Desulfuromonas acetoxidans Ya-2006 u Depozytariyi Instytutu mikrobiolohiyi i virusolohiyi im. D. K. Zabolotnoho NAN Ukrayiny $\mathrm{z}$ nadannyam reyestratsiynoho nomeru IMV B-7384 [Certificate of deposition of bacteria Desulfuromonas acetoxidans Ya-2006 strain at the Depository of D. K. Zabolotny Institute of Microbiology and Virology of the NAS of Ukraine with appropriation of registration number IMV B-7384] (in Ukrainian).

Gudz, S. P., Hnatush, S. O., Yavorska, G. V., Bilinska, I. S., \& Borsukevych, B. M. (2014). Praktykum z mikrobiologii' [Workshop on microbiology]. Ivan Franko National University of Lviv, Lviv (in Ukrainian)

Gudz, S., Hnatush, S., Peretiatko, T., Palianytsia, B., Kostruba, M., Podopryhora, O., \& Klym, I. (2004). Dynamika zmin tytru sul'fatvidnovlyuval'nykh bakteriy ta vmistu sul'fativ i sirkovodnyu u vodakh kar'yeru Yavorivs'koho sirkovoho rodovyshcha $\mathrm{v}$ protsesi yoho zatoplennya [Dynamics of changes in the titres of sulfate reducing bacteria and the content of sulfates and hydrogen sulfide in the waters of the Yavoriv sulfur deposit in the course of its flooding]. Visnyk of Lviv University, Biological Series, 37, 185-189 (in Ukrainian).

Hedderich, R., Klimmek, O., Kroger, A., Dirmeier, R., Keller, M., \& Stetter, K. O. (1999). Anaerobic respiration with elemental sulfur and with disulfides. FEMS Microbiology Reviews, 22(5), 353-381.

Hnatush, S., \& Maslovska, O. (2018). Sulfur-reducing bacteria Desulfuromonas acetoxidans IMV B-7384 under the influence of heavy metal ions. The Development of Natural Sciences. Izdevnieciba Baltija Publishing, Riga.

Kozlova, I. P., Radchenko, O. S., Stepura, L. H., Kondratyuk, T. O., \& Pilyashenko-Novokhatnyy, A. I. (2008). Heokhimichna diyalnist mikroorhanizmiv ta yiyi prykladni aspekty [Geochemical activity of microorganisms and its applied aspects]. Naukova Dumka, Kyiv (in Ukrainian).

Kuever, J., Rainey, F. A., \& Widdel, F. (2005). Family I. Desulfuromonaceae fam. nov. Genus I. Desulfuromonas / Desulfuromonas genus. Pfennig and Biebl, 1977. In: Brenner, D. J., Krieg, N. R., Staley, J. T., \& Garrity, G. M. (Eds.). Bergey's manual of systematic bacteriology. 2, Springer, New York.

Kuznetsov, A., Gradova, N., Lushnikov, S., Éngelkhart, M., Vaysser, T., \& Chebotareva, M. (2015). Prikladnaya ehkobiotekhnologiya [Applied Ecobiotechnology]. Binom Laboratoriya Znanij, Moscow (in Russian).

Lemos, R. S., Fernandes, A. S., Pereira, M. M., Gomes, C. M., \& Teixeira, M (2002). Quinol:fumarate oxidoreductases and succinate:quinone oxidoreductases: Phylogenetic relationships, metal centres and membrane attachment Biochimica et Biophysica Acta - Bioenergetics, 1553, 158-170.

Lengeler, J., Drevs, G., \& Shlegel, G. (Eds.). (2005). Sovremennaya mikrobiologiya. Prokarioty [Contemporary Microbiology. Prokaryotes]. Mir, Moscow (in Russian).

Maslovska, O. D., \& Hnatush, S. O. (2013). Vplyv ferum (III) cytratu na ATF-gidrolazy Desulfuromonas acetoxidans IMV B-7384 [The influence of ferric (III) citrate on ATP-hydrolases of Desulfuromonas acetoxidans IMV B-7384]. Visnyk of Dnipropetrovsk University, Biology, Ecology, 21(1), 3-8 (in Ukrainian).

Maslovska, O., \& Hnatush, S. (2015). Oxidative modification of proteins and specific superoxide dismuase activity of Desulfuromonas acetoxidans IMV B-7384 bacteria under the influence of ferric citrate. Microbiology and Biotechnology, 30, $34-40$.

Maslovska, O., Hnatush, S., \& Halushka, A. (2014). Zminy zhymokyslotnogo skladu klityn Desulfuromonas acetoxidans IMV B-7384 za vplyvu ferum cytratu [Fatty acids composition of Desulfuromonas acetoxidans IMV B7384 cells under the influence of ferric citrate]. Studia Biologica, 8(3-4), 8798 (in Ukrainian).
Maslovska, O., Hnatush, S., \& Katernyak, S. (2015). The activity of enzymes of glutathione antioxidant system of Desulfuromonas acetoxidans IMV B-7384 under the influence of ferric (III) citrate. Visnyk of Lviv University, Biological Series, 70, 213-220.

Moroz, O. M., Hnatush, S. O., Bohoslavets, C. I., Yavorska, G. V., \& Truchym, N. V. (2016). Vykorystannya bakteriyamy Desulfuromonas sp. yoniv ferumu (III) 1 manhanu (IV) yak aktseptoriv elektroniv [Usage of ferrum (III) and manganese (IV) ions as electron acceptors by bacteria of Desulfuromonas sp.]. Visnyk of Dnipropetrovsk University, Biology, Ecology, 24(1), 87-95 (in Ukrainian).

Moroz, O. M., Kolisnyk, Y. I., Podopryhora, O. I., Klym, I. R., Gudz, S. P., Borsukevych, B. M., \& Hnatush, S. O. (2008). Mikroflora vody ozera "Yavorivs'ke" [Microflora of "Javorivske" Lake water]. Scientific Bulletin of the Uzhgorod University, Series Biology, 24, 131-138 (in Ukrainian).

Moroz, O. M., Peretiatko, T. B., Klym, I. R., Borsukevych, B. M., Yavorska, G. V., \& Kulachkovsky, O. R. (2013). Sirkovidnovlyuval'ni bakteriyi ozera Yavorivs'ke: Deyaki morfolohichni, kul'tural'ni i fiziolohichni osoblyvosti [Sulfur reducing bacteria from Yavorivske Lake: Some morphological, cultural and physiological peculiarities]. Scientific Bulletin of the Uzhgorod University, Series Biology, 35, 34 41 (in Ukrainian).

Moroz, O., Gul', N., Galushka, A., Zvir, G., \& Borsukevych, B. (2014). Vykorystannja riznyh akceptoriv elektroniv bakterijamy Desulfuromonas sp., vydilenymy z ozera Javorivs'ke [Different electron acceptors usage by bacteria of Desulfuromonas sp. isolated from Yavorivske Lake]. Visnyk of Lviv University, Biological Series, 65, 322-334 (in Ukrainian).

Morozkina, E. V., \& Zvyagilskaya, R. A. (2007). Nitrate reductases: Structure, functions, and effect of stress factors. Biochemistry, 72(10), 1151-1161.

Prokhorova, A., Sturm-Richter, K., Doetsch, A., \& Gescher, J. (2017). Resilience, dynamics and interactions within a multi-species exoelectrogenic model biofilm community. Applied Environmental Microbiology, 83(6), e03033-e03016.

Richter, K., Schicklberger, M., \& Gescher, J. (2012). Dissimilatory reduction of extracellular electron acceptors in anaerobic respiration. Applied Environmental Microbiology, 78(4), 913-921.

Roden, E. E., \& Lovley, D. R. (1993). Dissimilatory Fe (III) reduction by the marine microorganism Desulfuromonas acetoxidans. Applied Environmental Microbiology, 59(3), 734-742.

Rosenberg, E., DeLong, E. F., Lory, S., Stackebrandt, E., \& Thompson, F. (Eds.). (2014). The procaryotes. Prokaryotic physiology and biochemistry. SpringerVerlag, Heidelberg.

Simonte, F., Sturm, G., Gescher, J., \& Sturm-Richter, K. (2017). Extracellular electron transfer and biosensors. In: Advances in biochemical engineering / biotechnology. Springer, Berlin.

Sung, Y., Ritalahti, K. M., Sanford, R. A., Urbance, J. W., Flynn, S. J., Tiedje, J. M. \& Löffler, F. E. (2003). Characterization of two tetrachloroethene-reducing, acetate-oxidizing anaerobic bacteria and their description as Desulfuromonas michiganensis sp. nov. Applied Environmental Microbiology, 69(5), 2964-2974.

Tarabas, O., Moroz, O., Hnatush, S., Yavorska, G., Zvir, G., \& Kovalchuk, M (2017). Ekoloho-trofichni hrupy mikroorhanizmiv vody ozera Yavorivs'ke [Ecological trophic groups of microorganisms of water of Yavorivske lake ]. Visnyk of Lviv University, Biological Series, 76, 166-178 (in Ukrainian).

Teng, Y., Xu, Y., Wang, X., \& Christie, P. (2019). Function of biohydrogen metabolism and related microbial communities in environmental bioremediation. Frontiers in Microbiology, 10(106), 1-14.

Vasyliv, O. M. Maslovska, O. D., Hnatush, S. O., Bilyy, O. I., \& Ferensovych, Y. P. (2016). Electric current generation by Desulfuromonas acetoxidans IMV B-7384 while application of ferric citrate, fuchsine and methylene blue. Microbiology and Biotechnology, 36, 42-49.

Vasyliv, O. M., Maslovska, O. D., Ferensovych, Y. P., Bilyy, O. I., \& Hnatush, S. O. (2015). Interconnection between tricarboxylic acid cycle and energy generation in microbial fuel cell performed by Desulfuromonas acetoxidans IMV B-7384. Proceedings of SPIE, 9493, 94930J-1-7.

Vasyliv, O., Bilyy, O., Hnatush, S., Kushkevych, I., \& Getman, V. (2011). The changes of spectroscopic characteristics of sulfur reducing bacteria Desulfuromonas acetoxidans under the influence of different metal ions. Proceedings of SPIE, 8152, 81520B-1-7.

Viti, C., Marchi, E., Decorosi, F., \& Giovannetti, L. (2014). Molecular mechanisms of $\mathrm{Cr}(\mathrm{VI})$ resistance in bacteria and fungi. FEMS Microbiology Reviews, $38(4), 633-659$. 